\title{
EVALUASI PERENCANAAN DAN PENGENDALIAN PROYEK PEMBANGUNAN AIR BERSIH DENGAN MENGGUNAKAN METODE LEAN PROJECT MANAGEMENT
}

\author{
Harpito, ST, MT ${ }^{1}$, Anwardi, ST ${ }^{2}$, MT, Lailatul Syifa Tanjung ${ }^{3}$ \\ $1,2,3$ Jurusan Teknik Industri, Fakultas Sains dan Teknologi, UIN Sultan Syarif Kasim Riau \\ Jl. HR. Soebrantas No. 155 Simpang Baru, Panam, Pekanbaru, 28293 \\ Email : harpito@uin-suska.ac.id, anwardi@uin-suska.ac.id, lailatulsyifat@yahoo.com
}

\begin{abstract}
ABSTRAK
Keterlambatan suatu proyek dapat terjadi akibat ketidakproduktifan setiap elemen - elemen yang terlibat didalamnya sehingga pada akhirnya akan terjadi pemborosan (waste). Untuk mengatasi permasalahan tersebut diperlukan perbaikan perencanaan dengan menggunakan metode Lean Project Management yang didalamnya dapat diidentifikasi waste, resiko, serta penjadwalan proyek dengan metode Critial Chain Project Management. Berdasarkan hasil identifikasi dalam pembangunan penyediaan air bersih di Kota Pekanbaru didapatkan waste yang berpotensi muncul adalah waiting, defects dan uneeded processing. Faktor kemungkinan resiko yang muncul pada saat pelaksanaan proyek adalah faktor cuaca buruk, adanya kerusakan pada alat kerja (komponen genset), keterlambatan datangnya raw material pipa, K3 (Kesehatan dan Keselamatan Kerja), Pencurian, kelalaian dan ketidakjujuran serta Kerusakan alat, properti ataupun fisik bangunan. Sedangkan penjadwalan dengan metode CCPM didapatkan penghematan waktu pengerjaan proyek sebesar 4 hari sehingga biaya yang dikeluarkan pihak pelaksana juga berkurang.
\end{abstract}

Kata Kunci : $\quad$ Critical Chain Project Management, Lean Project Management, Waste

\section{ABSTRACT}

This delay the project can result from unproductive any element which involved in this so that in the end will happen extravagance (waste). To solve the problem was needed peraikan planning by using the method lean project management in which cannot be identified waste, risk, and scheduling project with the methods critial chain project managementBased on the results of identification in the construction of clean water supply in pekanbaru obtained waste that has the potential to emerges is waiting, defects and uneeded processing. Factors the risks of who appeared at the time when of the project is a factor bad weather, the damaged on a work (components generator), delay the raw material pipe, K3 (occupational health and safety), theft, negligence and dishonesty and damage instrument, property or physical building. While scheduling with the methods ccpm obtained the saving of time the project of 4 day so it cost enforcement authorities also reduced.

Keywords : $\quad$ Critical Chain Project Management, Lean Project Management, Waste

\section{Pendahuluan}

Proyek konstruksi merupakan suatu kegiatan yang harus direncanakan sebelumnya dan memerlukan sumber daya yang lengkap, baik dari segi biaya, tenaga kerja, material, maupun peralatan. Perencanaan tersebut sebaiknya dilakukan secara detail dan tidak dilakukan berulang. Proyek pada umumnya memiliki batas waktu, artinya proyek harus diselesaikan sebelum atau tepat pada waktu yang telah ditentukan. Dalam dunia konstruksi, pemborosan merupakan salah satu faktor yang harus dihilangkan.Pemborosan(waste) dapat dihilangkan dengan suatu pendekatan lean. Lean berfokus pada identifikasi dan eliminasi aktivitas-aktivitas yang tidak bernilai tambah (non value added activities) dalam desain dan produksi (untuk bidang manufaktur) atau operasi (untuk bidang jasa) dan supply chain management yang berkaitan langsung dengan pelanggan (Womack dan 
Jones, 2003). Lean bertujuan untuk meningkatkan secara terus-menerus customer value melalui peningkatan terus-menerus rasio antara nilai tambah terhadap waste (the value-to-waste ratio) (Gasperz, 2007).

Dalam dunia konstruksi, pemborosan merupakan salah satu faktor yang harus dihilangkan. Hal ini dikarenakan, disamping pemborosan tidak menambah nilai dalam sebuah proyek, pemborosan juga merupakan salah satu faktor yang dapat mengakibatkan kegagalan dalam pengerjaan suatu proyek. Walaupun kegagalan tersebut tidak dapat dilihat secara nyata, namun jika berlangsung dengan intensitas yang besar dan terusmenerus maka kegagalan tersebut dapat terakumulasi dan dampaknya akan terlihat pada akhir proyek. Misalnya saja keterlambatan pengerjaan proyek dari jadwal yang direncanakan dan penambahan anggaran biaya dari yang semula direncanakan (Untu, 2014).

.PT. Budi Perkasa Panca Bersaudara merupakan salah satu perusahaan yang bergerak di bidang jasa konstruksi dalam melayani proyek pembangunan di kota Pekanbaru. Dalam hal ini PT. Budi Perkasa Panca Bersaudara akan melakukan proyek pengerjaan sumur dalam jaringan pipa dan kran bukit jamin Tenayan, Kota Pekanbaru. Jika dilihat dari pengerjaan proyek sebelumnya, perusahaan ini banyak mengahadapi permasalahan, salah satu permasalahan yang dihadapi adalah adalanya pembororan yang berpengaruh dengan penyelesaian proyek. Sehingga pemborosan tersebut harus segera direduksi agar pengerjaan proyek dapat diselesaikan sesuai dengan yang telah direncanakan sebelumnya.

\section{Tinjauan Pustaka}

Manajemen Proyek adalah penerapan ilmu pengetahuan, keahlian dan keterampilan, cara teknis yang terbaik dan dengan sumber daya yang terbatas, untuk mencapai sasaran dan tujuan yang telah ditentukan agar mendapatkan hasil yang optimal dalam hal kinerja biaya, mutu dan waktu, serta keselamatan kerja (Husen, 2009).

Menurut PMBOK (Project Management Body of Knowledge) Manajemen proyek adalah penerapan pengetahuan, keterampilan, peralatan, dan teknik untuk aktivitas proyek untuk memenuhi persyaratan proyek. Manajemen proyek dicapai melalui penggunaan proses seperti: memulai, perencanaan, pelaksanaan, pengendalian, dan penutup. Tim proyek mengelola pekerjaan proyek, dan pekerjaan biasanya melibatkan:

a. Tuntutan untuk bersaing: ruang lingkup, waktu, biaya, risiko, dan kualitas. b. Pemangku kepentingan yang berbeda kebutuhan dan harapan.

c. Diidentifikasi persyaratan.

Dalam proses sesungguhnya, pemimpin dalam organisasi proyek mengelola daan mengarahkan segala perangkat dan sumber daya yang ada dengan kondisi terbatas, tetapi berusaha memperoleh pencapaian paling maksimal yang sesuai dengan standar kinerja proyek dalam hal biaya, mutu, waktu dan keselamatan kerja yang telah ditentukan sebelumnya. Untuk mendapatkan produk akhir yang maksimal, segala macam kegiatan pada proses manajemen proyek direncanakan dalam sedetail dan seakurat mungkin untuk mengurangi penyimpangan-penyimpangan. Apabila ada tindakan koreksi dalam proses selanjutnya, diusahakan koreksi tersebut tidak terlalu banyak.

\section{Metode Penelitian}

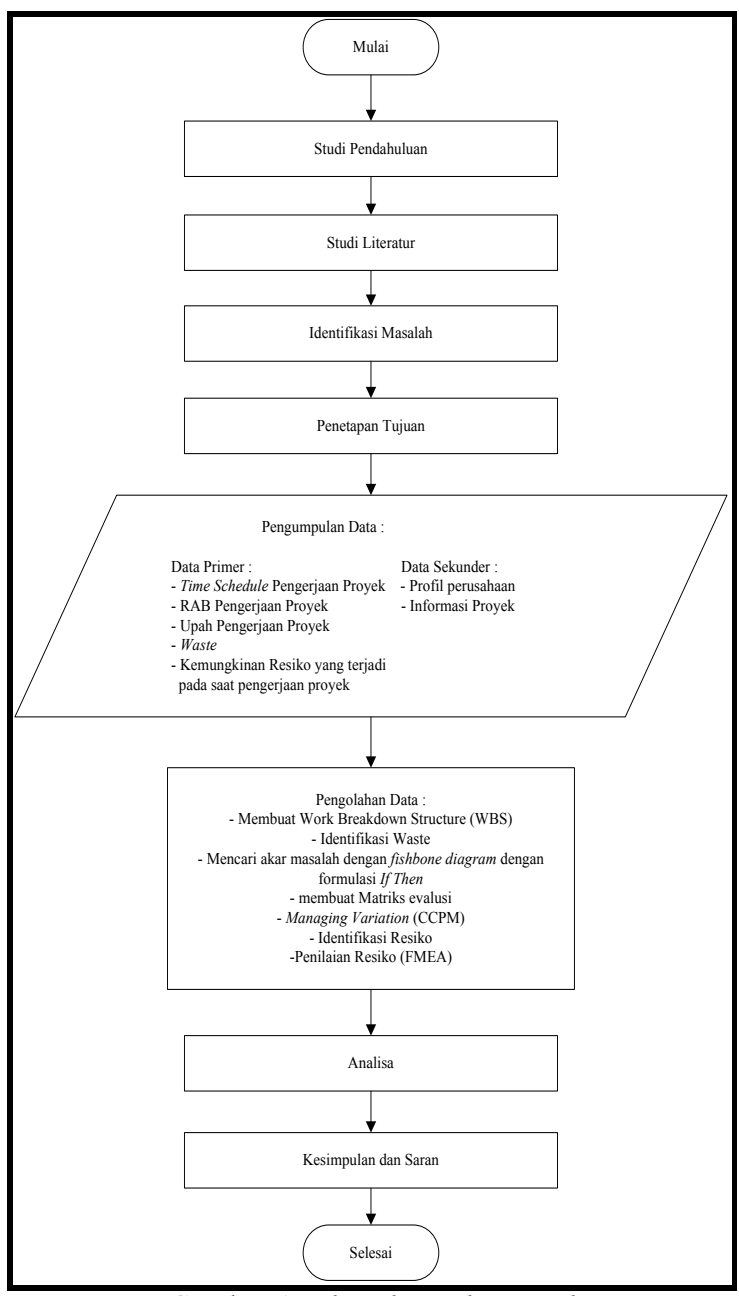

Gambar 1. Flowchart alur penelitian

Penelitian ini dilakukan pada pembangunan proyek pembangunan penyediaan air bersih / air minum oleh PT. Budi Perkasa Panca Bersaudara. Proyek ini 
berlokasi di jalan Tenayan Raya kota Pekanbaru. Topik yang dambil dalam penelitian ini adalah Lean Project Management. Lean Project Management merupakan pendekatan dalam perencanaan proyek, dengan fokus untuk meminimasi waste, mengidentifikasi permasalahan, serta mengestimasi segala kebutuhan yang berkaitan dengan proyek, sehingga pelaksanaan proyek dapat terlaksana dengan lebih efektif dan efisien.

\section{Lean Project Management}

Filosofi lean pertama kali diterapkan oleh perusahaan otomotif asal Jepang (Toyota). Konsep ini meyakini bahwa dengan mengidentifikasi dan mengeliminasi waste bersamaan dengan mengefisiensikan proses dapat mencapai suatu fase dimana customer value terpenuhi.

Lean management pertama kali dikembangkan di perusahaan Jepang terutama oleh perusahaan otomotif dari Jepang yang sangat terkenal di berbagai negara termasuk Indonesia. Lean management berarti metode sistematis dan integratif yang diimplementasikan secara berkesinambungan untuk meminimalisir dan mencegah adanya pemborosan ataupun prosesproses yang tidak bernilai tambah (non value added) dengan cara perbaikan berkelanjutan (continuous improvement) melalui pemetaan value stream (peta yang memperlihatkan proses nyata secara lebih rinci, mengandung informasi yang lengkap seperti tahapan proses, lead time, antrian, dan lain-lain), yang melibatkan seluruh karyawan baik dari tingkatan top management sampai tingkatan yang terendah (Untu, 2014). Sejalan dengan perkembangan, sekarang ini konsep lean management tidak hanya dapat diterapkan di industri manufaktur tetapi dapat diterapkan di perusahaan jasa, instansi pemerintah dan pelayanan kesehatan (rumah sakit dan sebagainya), maupun lembaga pendidikan, dapat menerapkan lean management untuk menghasilkan proses yang lebih efektif dan efisien, pelayanan yang lebih cepat, biaya yang lebih rendah, serta kualitas mutu dan pelayanan yang lebih baik. Pada dunia proyek, kosep lean dapat diterapkan pada pengerjaan proyek yang sedang berlangsur serta pengerjaan proyek yang sifatnya berulang. Hal ini dikarenakan karakteristik proyek yang berbeda-beda dan bersifat unik (Narsha, 2013).

\section{Peranan LPM pada proyek konstruksi}

Mengidentifikasi waste (non value-adding activities) dan kendala (resiko) yang berpotensi muncul saat pelaksanaan proyek, serta mengestimasi kebutuhan pelaksanaan proyek (waktu, biaya, sumber daya).

\section{Prinsip-prinsip LPM}

Adapun prinsip-prinsip dalam Lean Project Management (LPM)adalah sebagai berikut (Untu, 2014) :
1. Project System
a. Identifikasi waste dengan menggunakan diagram fish bone diagram dan formulasi if then
b. Identifikasi detail pekerjaan dengan Work Breakdown Structure (WBS),

2. Leading People

a. Identifikasi stakeholder yang berkaitan.

$\begin{array}{lc}\text { b. Mengelola stakeholder, dengan } \\ \text { pendefinisian } & \text { roles tiap-tiap }\end{array}$ stakeholder, dengan menggunakan matriks RICA, digunakan untuk proyek yang berhubungan dengan banyak pihak (biasanya hingga ratusan).

3. Chartering

Chartering merupakan suatu tahap pendefinisian visi dan tujuan proyek, dan menempatkan otoritas kepada pemimpin proyek untuk rencana proyek. Untuk memudahkan tahap chartering, maka manager proyek dapat menggunakan form charter, sehingga stakeholder yang berkaitan dapat memperoleh informasi dari proyek yang berkaitan.

4. Right Solution

Pengambilan solusi ini digunakan dalam pemilihan solusi untuk menangani waste yang berpotensi muncul saat pelaksanaan proyek.

5. Managing Variation

Variasi di dalam proyek diartikan ketidakpastian, untuk itu pihak pelaksana perlu memanage variasi, dengan cara mengestimasi sebelum pelaksanaan proyek baik dari segi biaya, waktu (penjadwalan) dan sumber daya yang digunakan.

a. Estimasi biaya. Tahap pertama dilakukan adalah mengestimasi biaya proyek dari kebutuhan material dan tenaga kerja (sebelum PPN 10\% dan dana kontingensi. Estimasi biaya dilakukan dengan merinci kebutuhan material dan tenaga kerja dari tiap jenis pekerjaan.

b. Estimasi jadwal. Perencanaan penjadwalan menggunakan metode Critical Chain Project Management (CCPM) bertujuan untuk menghindari student syndrom dan parkinson's law effects. Critical Chain Project Management (CCPM) adalah suatu metode penjadwalan yang dapat menjadi suatu alternatif baru sebagai solusi dari permasalahan tersebut. 
CCPM merupakan perkembangan dari metode Critical Path Management (CPM). Kelemahan metode penjadwalan CPM salah satunya adalah pemberian waktu terlalu lama panjang karena waktu cadangan diletakkan pada setiap aktivitas, sehingga sumber daya cenderung untuk menghabiskan waktu yang ada (parkinson's law effects), padahal pekerjaan dapat dilakukan lebih cepat dari itu atau bahkan pekerja cenderung melakukan pekerjaan dengan sungguh-sungguh pada akhirakhir batas waktu pekerjaan saja (Hanggoro, 2013).

c. Estimasi sumber daya. Kebutuhan jumlah pekerja berbanding terbalik dengan jumlah waktu yang dibutuhkan untuk menyelesaikan suatu pekerjaan. Semakin singkat (sedikit) waktu yang dibutuhkan untuk menyelesaikan pekerjaan maka kebutuhan pekerja semakin banyak, begitu pula sebaliknya.

6. Project Risk Management

7. Project Plan

Project Plan merupakan integrasi dari prinsip lean project management.

8. Eksekusi

a. Proses pengendalian proyek

b. Memonitor kinerja waktu

c. Mengembangkan sistem biaya atau jadwal terintegrasi

Salah satu tahapan penting dalam pendekatan lean adalah identifikasi aktivitasaktivitas mana yang memberikan nilai tambah dan tidak. Aktivitas yang tidak memberikan nilai tambah sebaiknya dikurangi untuk meningkatkan efisiensi dan efektivitas perusahaan. Dalam konteks ini, tipe aktivitas dalam organisasi dapat dibedakan menjadi tiga yaitu (Noer, 2012) :

1. Value Adding Activity (VA), aktivitas ini memberikan nilai tambah terhadap proses, baik pada aliran informasi dan aliran fisik proses. Misalnya pada proses pengecoran.

2. Non-value Adding Activity (NVA), aktivitas ini tidak memberikan nilai tambah terhadap produk. Aktivitas ini dapat dikategorikan sebagai waste yang dapat menyebabkan proses tidak berjalan secara efisien.
3. Non-value Adding but Necessary Activity (NNVA) yakni aktivitas yang tidak memberikan nilai tambah akan tetapi tetap dibutuhkan untuk menjalankan seluruh rangkaian proses. Aktivitas ini tidak dapat dihilangkan dan hanya bisa diminamilisir. Misalnya adalah waktu set-up mesin.

Womack et al. (1996 dikutip oleh Noer, 2012) mengidentifikasi delapan waste yang terdapat dalam sebuah proyek. Definisi waste yang dikembangkan oleh Womack menambah satu macam waste dari definisi yang sudah ada sebelumnya dimana pendefinisian waste sebelumnya terbagi menjadi seven waste (Noer, 2012). Perebedaan antara seven waste dengan eight waste Womack adalah penambahan waste baru yaitu design of goods and services that do not satisfy customer needs. Berikut ini adalah penjabaran dari eight waste:

1. Defects in production

2. Overproduction of items no one wants

3. Inventory waiting to be processed.

4. Unneeded processing

5. Unnecessary transport of goods

6. Unnecessary movement of people

7. People waiting for input to work on

Design of goods and services that do not satisfy customer needs

\section{Hasil dan Pembahasan}

\section{Identifikasi Waste}

Identifikasi dilakukan berdasarkan kondisi lapangan yang akan dibangun dan karakteristik proyek yang dilakukan melalui proses wawancara pada pihak - pihak yang terkait, seperti pimpinan perusahaan, konsultan serta pekerja lapangan serta melakukan pengamatan terhadap proyek yang dikerjakan sebelumnya. Identifikasi tersbeut diolah dengan menggunakan diagram fishbone dan formulasi if then. Berdasarkan hasi wawancara dengan pihak PT. Budi Perkasa Panca Bersaudara, waste yang paling berpotensi muncul dan berpengaruh pada proyek pembangunan sumur dalam dan jaringan pipa kota Pekanbaru dari 8 waste menurut Womack dan Jones tahun 1996 adalah waiting, defect dan Uneeded Processing. Berikut merupakan identifikasi waste waiting pada proyek pembangunan sumur dalam dan jaringan pipa kota Pekanbaru 


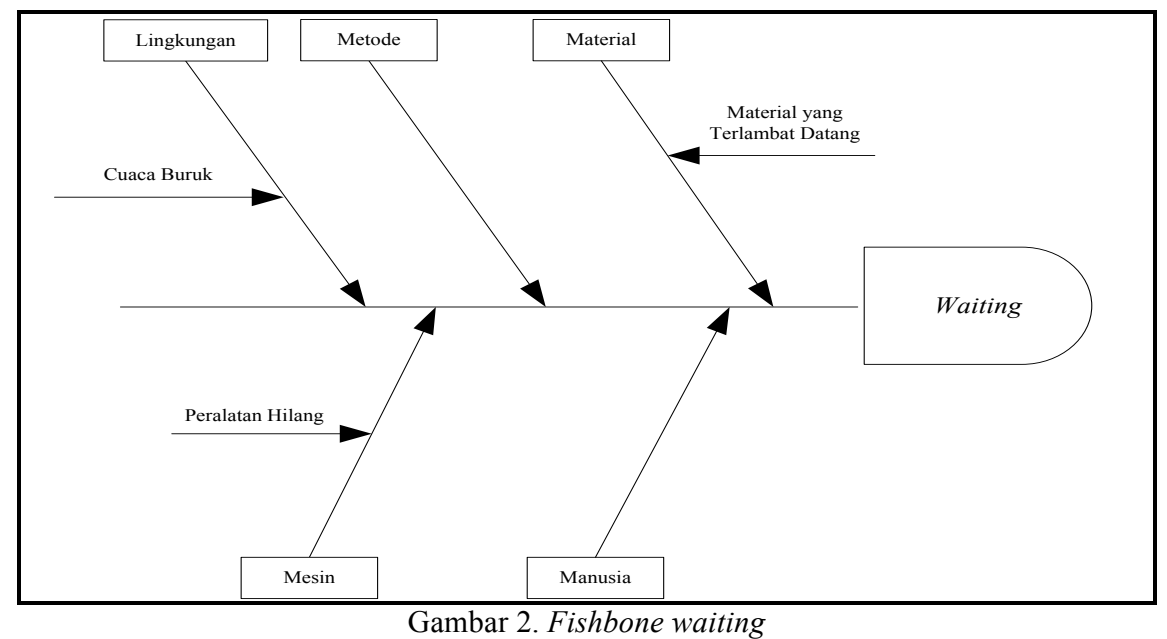

Penyebab terjadinya defects pada proyek ini dapat dilihat sebagai berikut :

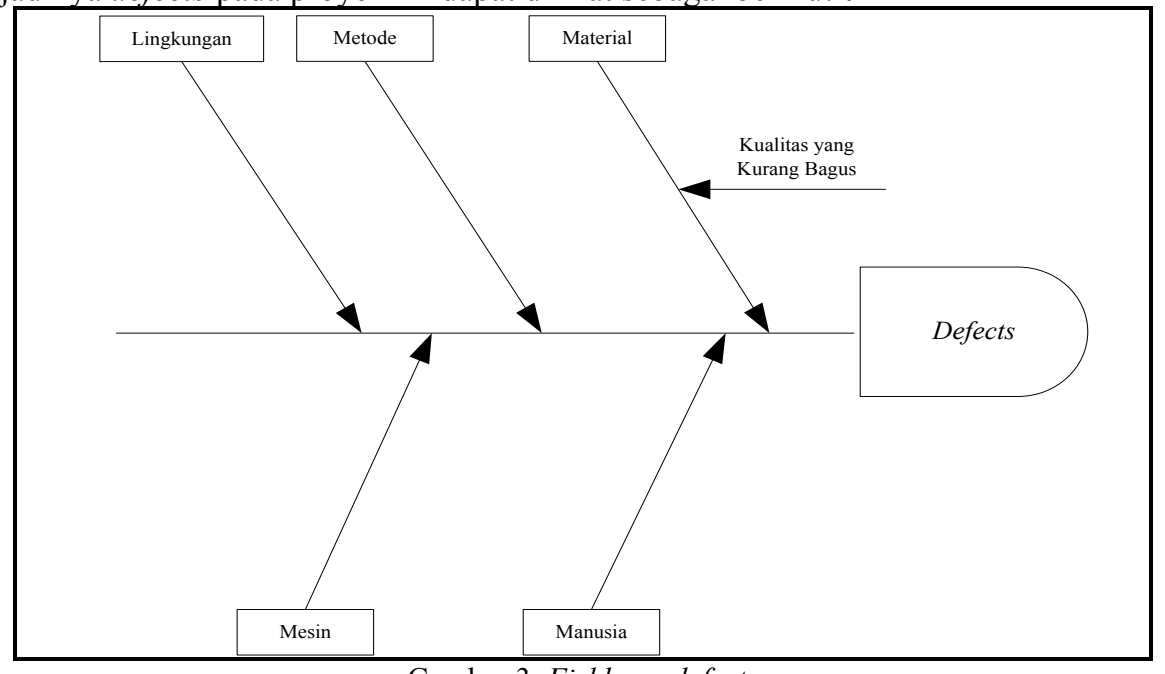

Gambar 3. Fishbone defects

Berikut merupakan akar masalah penyebab Uneeded Processing.

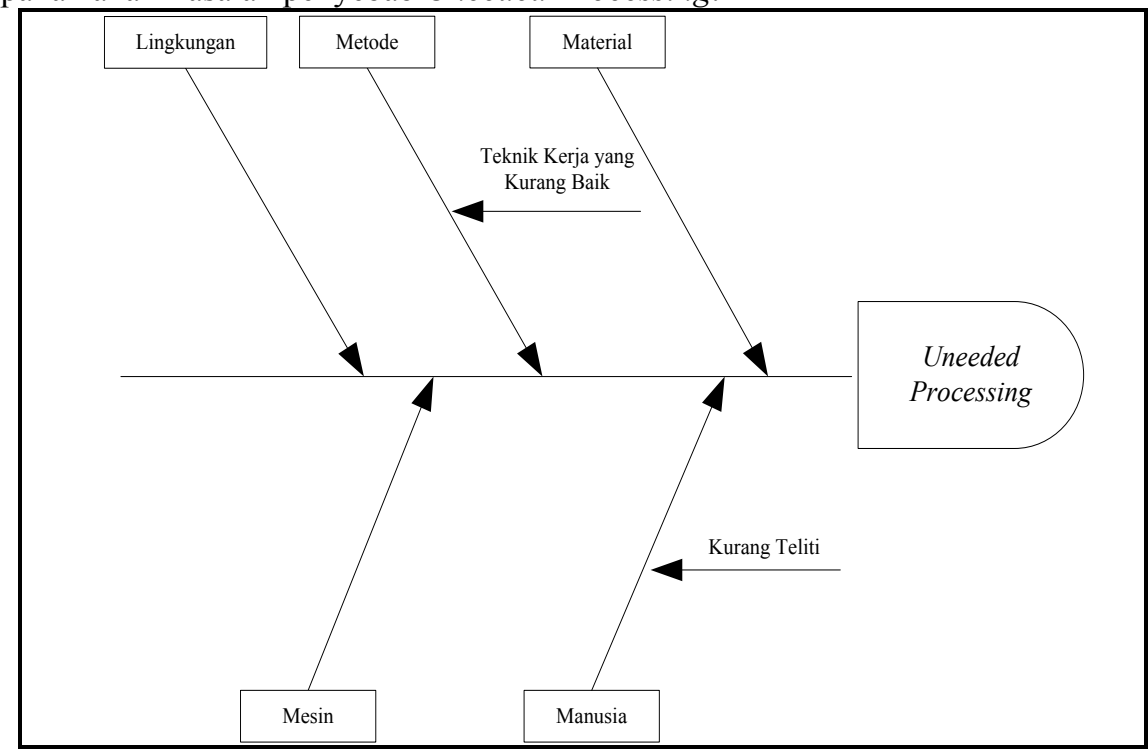

Gambar 4. Fishbone uneeded processing 
Dari peristiwa munculnya waste tersebut kemudian diolah ke dalam formulasi if then untuk dapat mengetahui tindakan - tindakan apa yang dapat ditempuh dengan tujuan untuk meminimumkan atau bahkan menghilangkan waste yang dapat diliihat pada tabel berikut ini :

Tabel 1.Controlling waste

\begin{tabular}{|c|c|c|}
\hline \multicolumn{3}{|c|}{ Controlling Waste } \\
\hline If & Then & When \\
\hline $\begin{array}{l}\text { Kualitas } \\
\text { material } \\
\text { kurang } \\
\text { bagus } \\
\text { (rusak) }\end{array}$ & $\begin{array}{l}\text { Melakukan } \\
\text { pembelian ulang } \\
\text { material yang rusak }\end{array}$ & $\begin{array}{l}\text { Saat } \\
\text { Pelaksanaan }\end{array}$ \\
\hline \multirow{2}{*}{$\begin{array}{l}\text { Material } \\
\text { terlambat } \\
\text { datang }\end{array}$} & $\begin{array}{l}\text { Melakukan pekerjaan } \\
\text { lain yang tidak } \\
\text { menggunakan } \\
\text { material yang belum } \\
\text { sampai pada lokasi } \\
\text { proyek }\end{array}$ & $\begin{array}{l}\text { Saat } \\
\text { Pelaksanaan }\end{array}$ \\
\hline & $\begin{array}{l}\text { Melakukan } \\
\text { percepatan pekerjaan } \\
\text { saat material sudah } \\
\text { datang }\end{array}$ & $\begin{array}{l}\text { Saat } \\
\text { Pelaksanaan }\end{array}$ \\
\hline \multirow[b]{2}{*}{ Cuaca buruk } & $\begin{array}{l}\text { Mengajukan surat } \\
\text { pengajuan } \\
\text { keterlambatan } \\
\text { pengerjaan }\end{array}$ & $\begin{array}{l}\text { Saat } \\
\text { Pelaksanaan }\end{array}$ \\
\hline & $\begin{array}{l}\text { Melakukan } \\
\text { percepatan pekerjaan } \\
\text { saat kondisi cuaca } \\
\text { sudah kembali } \\
\text { normal }\end{array}$ & $\begin{array}{l}\text { Saat } \\
\text { Pelaksanaan }\end{array}$ \\
\hline $\begin{array}{l}\text { Teknik kerja } \\
\text { yang kurang } \\
\text { bagus }\end{array}$ & $\begin{array}{l}\text { Melakukan pelatihan } \\
\text { terhadap pekerja } \\
\text { lapangan }\end{array}$ & $\begin{array}{l}\text { Sebelum } \\
\text { Pelaksanaan }\end{array}$ \\
\hline
\end{tabular}

(Sumber: Pengolahan data, 2017)

\section{Matriks Evaluasi}

Matris evaluasi bertujuan untuk mengetahui solusi mana yang layak dipilih berdasarkan beberapa kriteria yang sudah ditentukan sebelumnya dengan melakukan pembobotan.

Tabel 2. Matriks evaluasi material terlambat datang

\begin{tabular}{|c|c|c|c|c|c|}
\hline \multirow{3}{*}{ Kriteria } & \multirow{3}{*}{$\begin{array}{l}\text { Weight } \\
\text { factor }\end{array}$} & \multicolumn{4}{|c|}{ Material Belum Datang } \\
\hline & & \multicolumn{2}{|c|}{$\begin{array}{l}\text { Melakukan pekerjaan } \\
\text { lain yang tidak } \\
\text { menggunakan } \\
\text { material yang belum } \\
\text { sampai pada lokasi } \\
\text { proyek }\end{array}$} & \multicolumn{2}{|c|}{$\begin{array}{l}\text { Melakukan } \\
\text { percepatan pekerjaan } \\
\text { saat material sudah } \\
\text { datang }\end{array}$} \\
\hline & & Ranking & $\begin{array}{l}\text { Weight } \\
\text { score }\end{array}$ & Ranking & $\begin{array}{l}\text { Weight } \\
\text { score }\end{array}$ \\
\hline (1) & (2) & (3) & $(4)=(2 \times 3)$ & (5) & $(6)=(2 \times 5)$ \\
\hline Biaya & 3 & 4 & 12 & 3 & 9 \\
\hline Waktu & 3 & 4 & 12 & 2 & 6 \\
\hline $\begin{array}{l}\text { Dampak Terhadap } \\
\text { Hasil }\end{array}$ & 3 & 3 & 9 & 2 & 6 \\
\hline Resiko & 3 & 3 & 9 & 2 & 6 \\
\hline \multicolumn{2}{|c|}{ Total } & & 42 & & 27 \\
\hline \multicolumn{2}{|c|}{ GO/NOT GO } & \multicolumn{2}{|r|}{$G O$} & \multicolumn{2}{|c|}{ NOT GO } \\
\hline
\end{tabular}

Sumber: Pengolahan data (2017)
Tabel 3. Matriks evaluasi cuaca buruk

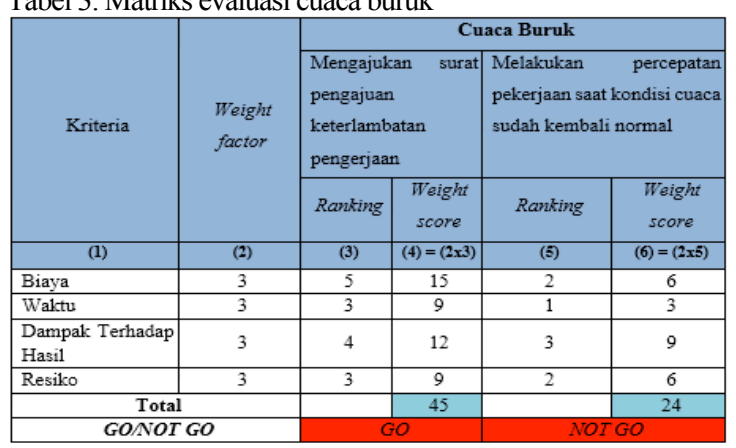

(Sumber : Hasil Identifikasi, 2017)

Tabel 4. Matriks evaluasi peralatan hilang

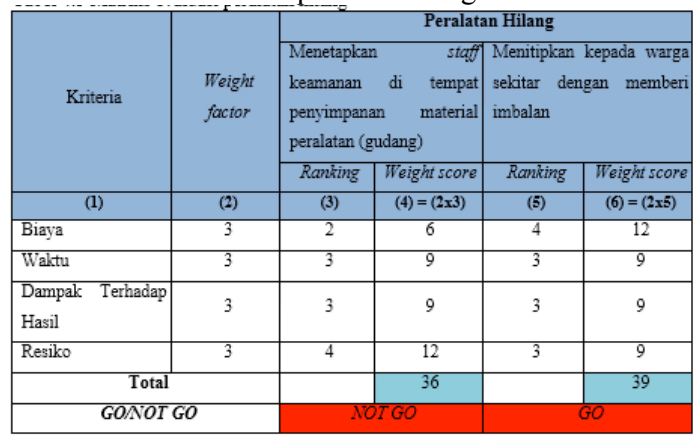

(Sumber : Hasil Identifikasi, 2017)

\section{Managing Variation}

Variasi di alam proyek dapat diartikan dengan ketidakpastian, untuk itu pihak pelaksana perlu memanage variasi, dengan cara mengestimasi sebelum pelaksanaan proyek baik dari segi biaya, waktu, serta sumber daya yang digunakan. Tujuan mengestimasi adalah agar manajer proyek dapat meramalkan atau memperkirakan waktu, biaya dan sumber daya yang akan digunakan saat pelaksanan proyek.

Dalam mengestimasi waktu proyek dilakukan penjadwalan dengan menggunakan metode CCPM dengan bantuan software Microsoft Project. Dalam melakukan penjadwalan durasi yang digunakan merupakan durasi yang dihilangkan sebesar $50 \%$ sehingga didapatkan buffer time dan beefing buffer. Sehingga berdasarkan pengolahan data dengan menggunakan metode CCPM maka didapat durasi optima pengerjaan proyek selama 114 hari kalender apabila seluruh buffer time digunakan dimana sebelumnya penjadwalan membutuhkan duras selama 100 hari kalender. Sedangkan apabila seluruh buffer time tidak digunakan maka durasi pengerjaan proyek menjadi 96 hari kalender sehingga didapatkan penghematan waktu pengerjaan proyek sebesar 4 hari sehingga biaya yang dikeluarkan pihak pelaksana juga berkurang. 


\section{Kesimpulan}

Berdasarkan pengolahan data yang dilakukan maka didapatkan kesimpulan bahwasanya waste yang akan berpotensi muncul pada pengerjaan proyek selanjutnya adalah waiting, defects dan uneeded processing sedangkan resiko yang berpotensi muncul adalah keterlambatan datangnya material, $\mathrm{K} 3$, kellaian, pencurian serta kerusakan material serta durasi optimal yang didapatkan berdasarkan metode CCPM didapatkan waktu optimal pengerjaan proyek (tanpa buffer time) adalah 96 hari kalender yang pada penjadwalan sebelumnya selama 100 hari kalender sehingga adanya penghematan waktu selama 4 hari sehingga akan menguntungkan pihak pelaksana baik dari segi waktu serta biaya yang dikeluarkan.

\section{Daftar Pustaka}

[1] Artika, Dian. Penerapan Metode Lean Project Management dalam Proyek Konstruksi pada Pembangunan Gedung DPRD Kabupaten Ogan Ilir. Jurnal Teknik Sipil dan Lingkungan Vol. 2 No. 1. Palembang, Maret 2014. http://www.ejournal.unsri.ac.id. Diakses pada tanggal 24 Oktober 2015.

[2] Ervianto, Wulfram I. Teori Aplikasi Manajemen Proyek Konstruksi. ANDI. Yogyakarta. 2004.

[3] Fauziah, Naily.Aplikasi Fishbone Analysis dalam MeningkatkanKualitas Produksi Teh pada PT Rumpun SariKemuning, Kabupaten Karanganyar. Tugas Akhir Fakultas PertanianUniversitas Sebelas MaretSurakarta. Surakarta, 2009. http://www.eprints.uns.ac.id. Diakses pada tanggal 3 Agustus 2009.

[4] Frederika, Ariany. Analisis Percepatan Pelaksanaan dengan Menambah Jam Kerja Optimum pada Proyek Konstruksi (Studi Kasus: Proyek Pembangunan Super Villa, Peti Tenget-Badung). Jurnal Ilmiah Teknik Sipil Vol. 14, No. 2. Juli, 2010. http://www.ojs.unud.ac.id.Diakses pada tanggal 22 November 2010.

[5] Gasperz, Vincent. Total Quality Manajemen. PT. Graha Ilmu. Yogyakarta. 2007.

[6] Gray, Clive. Pengantar Evaluasi Poyek, PT. Gramedia Pustaka Utama, Jakarta. 2007.

[7] Hanif, Yulianda Richma, Nendang Setyo Rukmi dan Susy Susanti.Perbaikan Kualitas Produk Keraton Luxury di PT. X dengan Menggunakan Metode Failure Mode And Effect Analysis (FMEA) dan Fault Tree Analysis (FTA). Jurnal Teknik Industri
Itenas No.03 Vol.03. Juli, 2015. http://www.jurnalonline.itenas.ac.id.

Diakses pada tanggal 8 Maret 2016.

[8] Husen, Abrar. Manajemen Proyek. Andi Offset. Yogyakarta. 2009.

[9] Karyono, Agus. Pendekatan Lean Manufacturing Untuk Menurunkan Waste Waiting Time dan Transportasi (Studi Kasus: CV. Riau Pallet). Tugas Akhir Universitas Negeri Sultan Syarif Kasim Riau. Juli 2014. http://www.repository.uinsuska.ac.id. Diakses pada tanggal 8 Oktober 2014.

[10] N. Narsha dan S. Nagabhushan. "Enhancing Project Management Efficiency using Lean Concepts". IOSR Journal of Mechanical and Civil Engineering (IOSR-JMCE) e-ISSN: 2278-1684,p-ISSN: 2320-334X, Volume 8, Issue $\quad 4 . \quad$ Oktober 2013. http://www.iosrjournals.org.Diakses pada tanggal 6 September 2013.

[11] Noer, Bustanul Arifin dan Dominggo Bayu Bagaskara. Perencanaan dan Pengendalian Proyek Periklanan Menggunakan Lean Critical Chain Project Management dan SCurve Mentoring. Jurnal Teknik Pomits Vol. $1 \quad$ No. $\quad 1.2012$. http://www.digilib.its.ac.id.Diakses pada tanggal 23 Juli 2012.

[12] Project manajemen Institute. A guide to the project management Body of knowledge (PMBOK Guide). Pensylvania. 2000.

[13] Sahid, Dadang Syarif Sihabudin.Implementasi Critical Path Method dan PERT Analysis pada Proyek Global Technology for Local Community. Jurnal Teknologi Informasi dan Telematika Vol.5. Desember 2010. http://www.dadang.komputer.pcr.ac.id. Diakses pada tanggal 29 Desember 2016.

[14] Sari, Erni. 2016. Analisis Resiko Proyek Pada Pekerjaan Jembatan Sidamukti - Kadu di Majalengka dengan Metode FMEA dan Decision Tree. Jurnal J-Ensitec: Vol 03 No. 01. Juli 2016. http://www.jurnal.unma.ac.id. Diakses pada tanggal 8 November 2016.

[15] Santoso, Budi. Manajemen Proyek. Graha Ilmu. Surabaya. 2008.

[16] Setiawan, Pricilia Febriana. Manajemen Resiko Proyek Vale Di Pt. Multipanel Intermitra Mandiri. Tugas Akhir Fakultas Teknologi Industri Universitas Atma Jaya Yogyakarta. 2014. http://www.ejournal.uajy.ac.id.Diakses pada tanggal 20 November 2016.

[17] Soeharto, Iman. Manajemen Proyek Industri: Persiapan, Pelaksanaan, Pengelolaan. Erlangga. 1992. 
[18] Tilaar, Wartinah T.A.M dan Ruslan M. Yunus. Penjadwalan Proyek Pembangunan Gedung Research CentreUniversitas Tadulako dengan Menggunakan Microsoft Project. Jurnal Infrastruktur Vol. 3 No. 1. 2013. $\quad$ http://www.jurnal.untad.ac.id. Diakses pada tanggal 3 Januari 2017.

[19] Untu, Silvia Hermina Stevania, Ariestides K. T. Dundu,dan Robert J. M. Mandagi. Penerapan Metode Lean Project Management dalam Perencanaan Proyek Konstruksi (Studi Kasus : Pembangunan Gedung Mantos Tahap III). Jurnal Sipil Statik Vol. 2 No. 6. September, 2014. http://www.download.portalgaruda.org. Diakses pada tanggal 27 November 2014.

[20] Wowor, Fransisko Noktavian, Walangitan dan Malingkas. 2013. "Aplikasi Microsoft Project dalam Pengendalian Waktu Pelaksanaan Pekerjaan Proyek". Jurnal Sipil Statik Vol.1 No.8. 2013. https://www.ejournal.unsrat.ac.id. Diakses pada tanggal 10 Januari 2017.Artika, Dian. 2014. "Penerapan Metode Lean Project Management dalam Proyek Konstruksi pada Pembangunan Gedung DPRD Kabupaten Ogan Ilir". Jurnal Teknik Sipil dan Lingkungan Vol. 2 No. 1. 